\title{
Towards a theoretical underpinning of the book arts: Applying Bakhtin's dialogism and heteroglossia to selected examples of the artist's book
}

\begin{abstract}
Author:
David Paton

Affiliation:

${ }^{1}$ Department of Visual Art, Faculty of Art, Design and Architecture, University of Johannesburg, South Africa
\end{abstract}

\section{Correspondence to:}

David Paton

Email:

dpaton@uj.ac.za

Postal address:

PO Box 524, Auckland Park

2006, South Africa

Dates:

Received: 27 Jan. 2012

Accepted: 07 Aug. 2012

Published: 13 Nov. 2012

How to cite this article:

Paton, D., 'Towards a

theoretical underpinning

of the book arts: Applying

Bakhtin's dialogism and

heteroglossia to selected

examples of the artist's

book', Literator 33(1), Art.

\#353, 11 pages. http://dx.doi

org/10.4102/lit.v33i1.353

Note:

This article was written as part of, and functions within the scope of a

larger research project entitled Transgressions and boundaries of the page: $A$ transdisciplinary exploration of a practice-based research project by means of the artist's book conducted by the subject groups Graphic Design, Creative Writing and Art History at the Potchefstroom Campus of the North-West University, South Africa.

Project web page: www. bookboek.co.za

(C) 2012. The Authors. Licensee: AOSIS OpenJournals. This work is licensed under the Creative Commons Attribution License.
Recent research projects and conferences devoted to the book arts have responded to Johanna Drucker's 2005 call that a more rigorous theoretical underpinning of the field of book art production needs to be established urgently. Yet these projects and conferences, resultant from the participation of artists and other practitioners in the field, not surprisingly, have biased their discussions on the book arts towards practice and away from theory. In establishing that a need still exists for an appropriate lens through which the artist's book might be more rigorously and theoretically examined, this article explored the following publications: Stéphane Mallarmé and Marcel Broodthaers's Un coup de dés, Buzz Spector's reductive Marcel Broodthaers, Ulises Carrión's For fans and scholars alike and Helen Douglas and Telfer Stokes's Real fiction. These specific examples, and particularly their relationships and dialogues which each other, were examined through a lens provided by the Russian philosopher and literary theorist Mikhail Bakhtin's writings on dialogism and heteroglossia. These critical terms, which demonstrate the dialogic, multivocal and heteroglot voices between works in history and within themselves, as cultural utterances, were shown to be appropriate and useful frames for the analysis of particular qualities which enunciate the presence of artists' books in the world: self-consciousness, discursive perceptivity and reflexivity. I therefore, applied Bakhtin's notions of dialogism and heteroglossia to the task of proposing a theoretical foundation for the artist's book, as a dynamic visual language, which is relational and engaged in a process of endless redescriptions of the world.

Ondersoek na 'n teoretiese onderskraging van boekkuns: Die toepassing van Bakhtin se dialogisme en heteroglossia op geselekteerde voorbeelde van kunstenaarsboeke. Onlangse navorsingsprojekte en konferensies oor boekkuns het gereageer op Johanna Drucker se oproep in 2005 dat noodsaaklike navorsingswerk gedoen moet word om 'n deegliker teoretiese basis vir die terrein van boekkunsproduksie te vestig. Die deelname van kunstenaars en ander praktisyns van boekkuns veroorsaak dat gesprekke en besprekings noodwendig en voorspelbaar neig na die praktyk en weg van die teorie. In die lig van die behoefte aan die bepaling van 'n toepaslike visie waarvolgens die kunsboek meer eksplisiet, ook teoreties, ondersoek kan word, ondersoek hierdie artikel Stéphane Mallarmé en Marcel Broodthaers se Un coup de dés publikasies, Buzz Spector se simplifiserende Marcel Broodthaers, Ulises Carrion se For fans and scholars alike, en Helen Douglas en Telfer Stokes se Real fiction. Hierdie spesifieke voorbeelde, en hulle onderlinge verbande en dialoog met mekaar, word ondersoek vanuit die perspektief van die Russiese filosoof en literêre teoretikus Mikhail Bakhtin se werk oor dialogisme en heteroglossia ('ander-tongigheid'). Hierdie begrippe demonstreer die dialogiese, multivokale en veeltongige wisselwerking tussen en binne historiese werke as kultuuruitings. Deur die analise toon ek aan dat hierde begrippe toepaslike en funksionele raamwerke uitmaak vir die analise van spesifieke aspekte wat die teenwoordigheid van kunstenaarsboeke aankondig in die wêreld: selfbewustheid en omvattende diskoers wat wederkerend toepaslik is. Ek stel voor dat Bakthin se idees oor dialogisme en heteroglossie gebruik word as die teoretiese begronding van die kunstenaarsboek as ' $n$ dinamiese visuele taal wat in 'n netwerk van ander tekste staan en deel is van die proses van die eindelose herbeskrywing van die wêreld.

\section{Introduction}

In this article I respond to Johanna Drucker's (2005:3) rebuke that the critical apparatus for artists' books is about as sophisticated as that which exists for needlework, decoupage, and other 'crafts', and that its theoretical foundation doesn't yet exist. Drucker's challenge responded to Dick Higgins's much earlier call for critical theoretical work to be undertaken when he stated that '... the language of normative criticism is not geared towards the discussion of an experience, 
which is the main focus of most artists' books' (Higgins in Lyons 1985:12). Recent book arts conferences ${ }^{1}$ and research projects $^{2}$ continue to place any theoretical debate on the artist's book firmly within practice. Clearly, what is needed is an articulate voice, from within the given practice, which points decisively towards theory. As the purpose of the 2007 Action/Interaction: Book/Arts Conference (A/I) was to focus attention upon theoretical underpinnings of the broad field of the book arts, to raise the level of critical discourse and to support a more rigorous critique and analysis of artists' books, it is revealing that conference co-ordinator Elisabeth Long (2007:6) stated: 'Did we achieve our goals? Only in part, though I believe that the conference provided seeds for the type of ongoing discussion that we were searching for'.

With the need for an articulate voice in mind, it is instructive that a recent piece of academic writing in South Africa focuses some attention on this gap in the theoretical underpinning of artists' books. Keith Dietrich (2011:1-16), in his inaugural address at Stellenbosch University, argues that the artist's book inhabits an 'ambiguous space between artwork and book' and within '... this undefined space where boundaries dissolve, the bookwork transcends the threshold from one space to another' (Dietrich 2011:14). Dietrich evokes Victor Turner's (1967:97) concept of liminality and the liminal space, as a state 'betwixt and between' all the recognised fixed points in space-time of structural classification. For Dietrich (2011:14) it is clear that when examining liminality one is, in effect, dealing with the unstructured, a condition allied to what Turner terms 'the unbounded, the infinite, the limitless' (Turner 1967:98). Thus, liminality can be read as an intersection where ideas and concepts are in constant states of confrontation and intercession, a rich theoretical space for describing the artist's book. Dietrich (2011:14) then joins the space between these states of confrontation and intercession and cultural hybridity by evoking Homi Bhabha's (1994:5) idea of liminality as an 'interstitial passage between fixed identifications'. For Dietrich the notion of liminality 'is important in describing some of the phenomena regarding artists' books ... namely their transdisciplinary, transcultural and hybrid nature' (Dietrich 2011). Dietrich continues:

This liminal state unlocks a hybrid space, or what Bhabha refers to as a 'Third Space of enunciation'. ... Positioned betwixt and between the world of books and the conventional world of art, the artist's book does not quite belong to either of these worlds and, despite this lack of stability, this liminal space allows for a freedom of movement and the dynamic exchanges of ideas, concepts and methods of working. (p. 15)

1.Examples of recent conferences are: the Pyramid Atlantic Book Arts Fair \& Conference Silver Spring, Maryland, November 2006, the Codex International Book Fair, Berkeley, February 2007 and the Action/Interaction: Book/Arts Conference (A/I), Columbia College Center for Book and Paper Arts, Chicago, June 2007. The most recent conference, the College Book Arts Association's (CBAA) Time, Sequence \& Technology: Book Art in the 21st Century, took place in San Francisco in January 2012.

2.A year after the publication of $A / I$ 's conference proceedings, Sarah Bodman and Tom Sowden of the Centre for Fine Print Research (CFPR), University of the West of England (UWE) Bristol, took up the challenge. In consultation with an internation community of artists, educators, researchers, students, presses, publishers, community of artists, educators, researchers, students, presses, publishers, librarians, curators, dealers, collectors and others who were whelved in the (2010) Bodman and Sowden's A manifesto for the book (2010) is perhaps the mo (2010) Bodman and Sowden's A manifesto for the book (2010) is perhaps the most comprehensive programmatic statement regarding contemporary internationa book arts practice to date.
What is of particular interest to me in this reference to Bhabha's (1994:86) notion of the Third Space as interstitial, liminal, unfixed and, thus, undefined, is its resonance with Bakhtin's notion of his own ideas and work occupying '... spheres that are liminal' operating ' $\ldots$ on the borders of ... disciplines, at their junctures and points of intersection' (Bakhtin quoted in Holquist 2002:14). Bhabha's concept of a space of enunciation, that focuses theoretical discourse upon articulation, invokes Drucker's (2007:161) reference to the exploitation of technical and graphic conceits inherent in artists' books. These conceits call attention to the conventions by which, through constant exposure, a book normally neutralises its identity. Drucker (2007:161) describes this as a book's theoretical operation of enunciation by which attention is called to its own processes and structure; which are acts through which a bookwork demonstrates its own making, and speaks for or represents itself rather than allowing itself to be spoken for or justified by external agencies.

For the purposes of attempting to construct a tentative theoretical foundation for the artist's book as a liminal form I argue, here, through an investigation of selected examples, that dialogism and heteroglossia can be used to enunciate the theoretical operations of artist's books, which are their:

- self-consciousness

- discursive perceptivity

- self-reflexivity (or bookness).

\section{Dialogism and the artist's book}

The term dialogism ${ }^{3}$ has its origin in the literary theoretical works of the Russian philosopher Mikhail Bakhtin (1895-1950). In his writings, ${ }^{4}$ Bakhtin's dialogism implies the maintaining of a continual dialogue with other works of literature and other authors, which are multiple communications between words, phrases, works and bodies of work with their literary past. ${ }^{5}$ For Bakhtin, all language, indeed every thought, appears dialogically responsive to things that have been said before and in anticipation of things that will be said in response to these statements. All language and the ideas which language contains and communicates, is dynamic, relational and is engaged in a process of endless redescription of the world (Besley \& Peters 2011:95). This complex and intertextual dialogue, reminiscent of Bhabha's Third Space, is made clear in Bakhtin's view of his own work which:

... must be called philosophical ... it is not a linguistic, philological, literary or any other particular kind of analysis. ... On the other hand, a positive feature of our study is this: [it moves] in spheres that are liminal, i.e., on the borders of all the aforementioned disciplines, at their junctures and points of intersection. (Bakhtin cited in Holquist 2002:14)

3.Michael Holquist (2002:15) notes that the term dialogism is used by scholars as a means of '... categorizing the different ways he meditated on dialogue' but was 'never used by Bakhtin himself'. (see Holquist 2002).

4.Examples of his work include: Problems of Dostoevsky's poetics (1984), Rabelais and his world (1984) and the essays published in English as The dialogical imagination (1981). Note that these dates all refer to the first English translations. The origina Russian transcripts date to 1919 (Art and answerability).

5.Dialogism opposes monologic works of literature - military orders, instructions, rules and even epic poetry, in which any orientation of the work towards a past or a future context, or history or voice is minimised, which prompts, rather, obedience, acquiescence or no interactivity at all. 
In these terms, dialogism implies a polyvocality in which various registers and languages interact and respond to each other. Yet this view of Bakhtin's work also underscores dialogism's resistance to 'being confined to any exclusively 'literary' application. Indeed, the fixity of boundaries between 'literary' and 'extra-literary' discourse is precisely what it questions' (Holquist 2002:107), and consequently opens up a space for dialogism's application to the analysis of scripto-visual texts of which the artist's book is an appropriate example. In fact, Bakhtin's words might act as a foundation for Drucker's study of the artist's book in which she describes her survey's scope as 'a zone of activity ... made at the intersection of a number of different disciplines, fields, and ideas' (Drucker 2007:1).

\section{Stéphane Mallarmé and Marcel Broodthaers}

I begin by locating dialogism in relation to Marcel Broodthaers's response to the French Symbolist poet Stéphane Mallarmé's 1914 publication ${ }^{6}$ Un coup de dés jamais n'abolira le hasard (A throw of the dice will never abolish chance).

Mallarmé's typography and material presentation suggests the movement of a listing ship and spreads across two pages 'creating not only a more spacious configuration but also a more challenging experience of reading' whilst 'certain phrases ... are abruptly and wittily cut by the boundaries of the page' (Arnar 2011:206), causing a reader to move between recto and verso pages whilst having to read across the gutter. Its unorthodox layout makes references to electrical and magnetic energies which function, metaphorically, as 'an invisible force uniting the dispersed fragments of text' (Arnar 2011:218). Page-turning ignites a 'spark' which, Mallarmé believed, connected the reader and the work (Arnar 2011:221). By exploiting the textual, visual, and temporal elements of the book, Mallarmé explicitly expressed his desire to protect the unique visual character of his text. Regarding this, the poem was a visual composition in its own right without the proposed illustrations of his friend Odilon Redon (Arnar 2011:204). Un coup de dés brought together two forms of the book: The avant-garde book (as precursor of the artist's book) 'whose revolutionary and emancipatory goals gestured outward, and the livre d'artiste, whose concessions to rarity and originality gestured inward' (Arnar 2011:238).

If this gesturing dialogically 'refracts' (to use Bakhtin's term), it is for the purpose of operationalising the fact that each element of a work has a history of usage to which it responds, whilst also anticipating future responses. ${ }^{7}$

6.Anna Sigrídur Arnar (2011:343) provides the following information on this work Mallarmé's poem was first published in the journal Cosmopolis in May 1897. From
extant proofs corrected by him, this version represents only a partial fulfillment of extant proofs corrected by him, this version represents only a partial fulfillment of his ideas for the poem. In publications completed after his death, the 1914 edition published by the Nouvelle revue Française disregards several particular specification Mallarme made before his death, amongst these, the specific Didot font to be used The 1980 edition Paris: Change errant/ d'atelier responds carefully to Mallarmé's notes and corrected extant proofs in which a few textual changes and adjustments in capitalisation are made. Gallimard's 2003 version, based on the 1914 publication, is what I use in this article and its illustrations. Francoise Morel's 2007 edition, published by La table rond include facsimile reproductions of Mallarmé's corrected proofs and the Cosmopolis version. Finally, the 2007 Ypsilon published edition uses Didot type face and includes reproductions of Redon's lithographs (c1900) intended for the poem by Ambrose Vollard, but which were never published.

7.In dialogical terms, Mallarmé's version could anticipate Broodthaers's version through the manner in which the original textual layout broke with the typographic conventions of its day. This influenced the visual typographies of later Futurist, Dada and Constructivist artists who, themselves, influenced postmodern typography as well as that of Broodthaers. It is here that the dialogical power of Mallarmé's work comes to the fore.
Broodthaers's version, titled Un coup de dés jamais n'abolira le hasard: Image (1969), is a dialogical refraction of Mallarmé's poem in its intention and physical production. Broodthaers's exploitation of varying translucencies of substrate expands and complicates Mallarmé's original concept of reading back and forth across the gutter, but without any interference in the act of reading. These conceptual and technical decisions reinforce the dialogical relationship between Mallarmé and Broodthaers, in that the optical qualities present in the post Cosmopolis versions of Mallarmé's typographic layout can be exploited in the sequential and material possibilities of the artist's book. Broodthaers's work is a careful and particular response to Mallarmé's edition, ${ }^{8}$ and to objects more generally, as signs of negation. Drucker (2007) describes the work as follows:

a conceptual transformation of [the] earlier piece, skilfully citing and restating its premises in a manner which dialogues across historical time and cultural assumptions.... Where each line of the poem should lie on the page a dark black line, simple, geometric, stark is placed in its stead. This is a physical equivalent, a moral inequivalent, a recapitulation and obliteration. (p. 115)

The Broodthaers version is not a witty play on the formal, typographic conventions so important to Mallarmé, and Drucker (2007) reminds us that even as:

it elevates the structure of the work to a concept worthy of study in its own right ... Broodthaers offers a conceptual analysis of Mallarmé's poem across the distance of nearly a century. (pp. 115-116)

Birgit Pelzer (1987:157-181), however, argues for an even deeper dialogical analysis of the two works than Drucker's elevation of structure and conceptual analysis. In this work, argues Pelzer, Broodthaers states that the subject 'figures poorly in its meaning' and, 'that it is caught up ... in the network of social relations that play out the symbolic representation with which the subject is charged' (Broodthaers cited in Pelzer 1987:159). Broodthaers's intention then is to 'restrict the notion of the subject' by interrogating the 'loss of the real' stating that, 'to be represented, a thing must be lost' (Broodthaers cited in Pelzer 1987:158).

In dialogical terms, Broodthaers's oeuvre would be particularly receptive to the assertion that 'the very capacity to have consciousness is based on otherness' (Holquist 2002:18). Broodthaers's dark black, geometric, inequivalent and obliterating linear metaphor, halts any metonymic drift away from the thing which is signalled as lost, evoking Mallarmé's own use of 'magnetic' typography as a 'way of averting the falling off ... [through] recourse to some absolute power, such as Metaphor' (Mallarmé cited in Pelzer 1987:181).

Broodthaers's typographic obliteration of Mallarmé's work implies what Bakhtin terms intentional hybridisation. Broodthaers's obliteration is one linguistic consciousness which explicitly represents another consciousness (Mallarmé's) with each belonging to a different system of language (Evans 2011:63).

8.Broodthaers's 1969 edition consists of ten unbound copies printed on twelve aluminium sheets along with ninety copies printed on translucent paper, with two sheets of white card cut to the size of the book, to enable the reader to isolate individual pages, and three hundred copies on normal paper which also allowed the ink impressions in versō foliō (on the turned page) to be visible. 

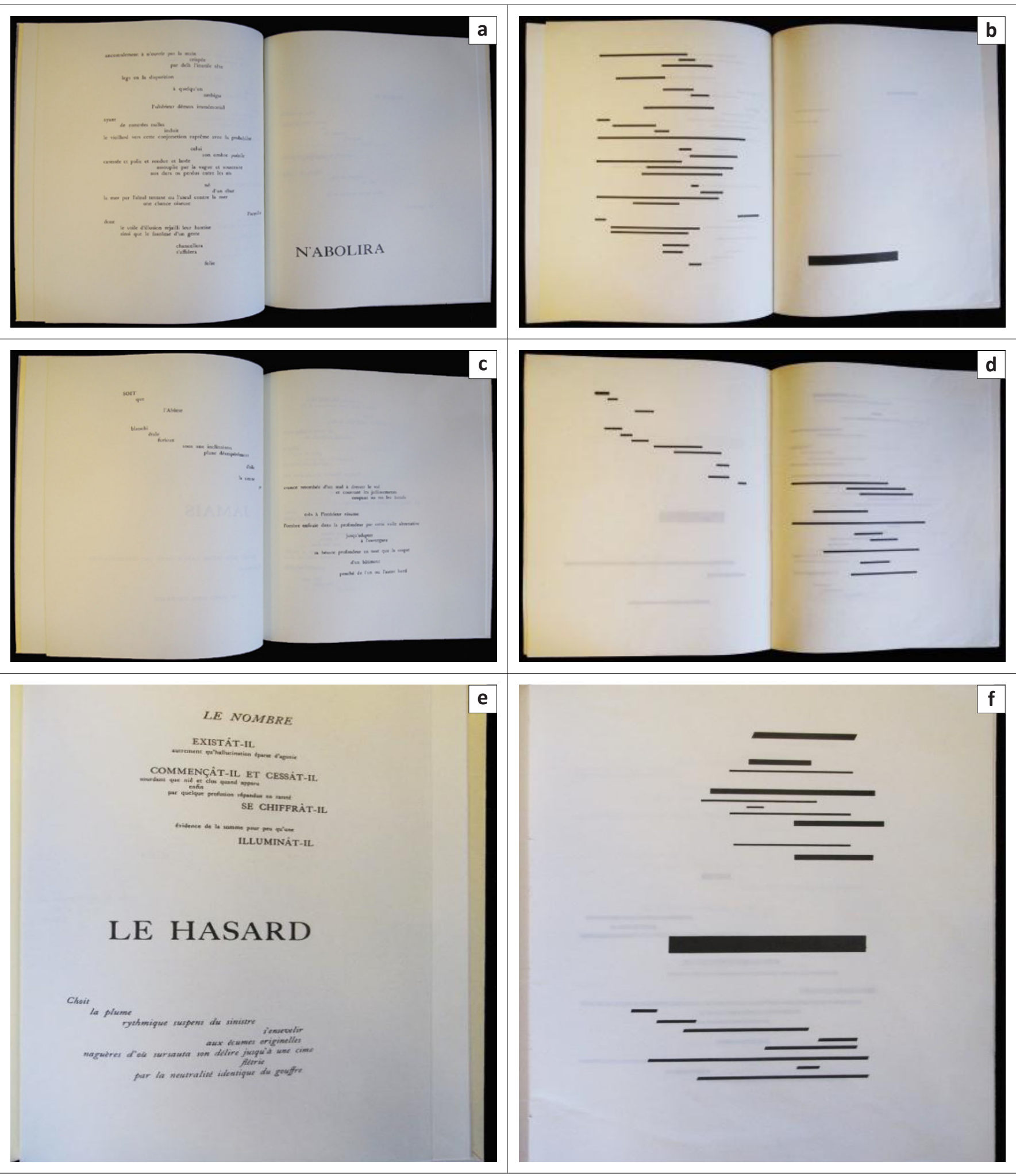

Source: Mallarmé, S., [1914] 2003, Un coup de dés jamais n'abolira le hazard, Gallimard, L'imprimerie Floch, Paris/Mayenne. Broodthaers, M., 1969, 'Un coup de dés jamais n'abolira le hasard: Image', Galerie Wide White Space and Köln: Galerie Michael Werner, Antwerp. (Artist's book)

Collection: National Art Library, V \& A Museum, London

Photography: David Paton

Images reproduced courtesy of the National Art Library, V \& A Museum, London and C DACS 2012

Figure 1: (a) Page 6 (verso and recto) of Stéphane Mallarmé's 1914 version of Un coup de dés jamais n'abolira le hazard which ends: 'Engagements from which the veil of illusion splashes back their hauntedness how the phantom of a gesture will pitch will fall madness WILL ABOLISH'; (b) Page 6 (verso and recto) of Marcel Broodthaers' 1969 Un coup de dés jamais n'abolira le hasard: Image in which a careful obliteration of Mallarme's positional and typographic density is undertaken; (c) Page 4 of Stéphane Mallarmé's 1914 version of Un coup de dés jamais n'abolira le hazard. The text (illustrated here, verso) begins with: 'BE IT that the Abyss blanched unbound furious under an incline'. The page spread is completed with: 'its yawning depth as great as the hull of a vessel listed to one or the other side' on the recto; (d) Page 4 (verso and recto) of Marcel Broodthaers' 1969 Un coup de dés jamais n'abolira le hasard: Image in which a careful obliteration of Mallarme's positional and typographic density is undertaken; (e) Page 10 (recto) of Stéphane Mallarmé's 1914 version of Un coup de dés jamais n'abolira le hazard. The partial text illustrated here, demonstrates the need to read across the gutter to complete it. '(IT WAS) THE NUMBER (born of stars) WERE IT TO EXIST other than as a scattered hallucination of dying ...'; (f) Page 10 (recto) of Marcel Broodthaers' 1969 Un coup de dés jamais n'abolira le hasard: Image in which a careful obliteration of Mallarme's positional and typographic density is undertaken. 
Broodthaers's belongs to image and Mallarmé's belongs to text, and are, hence, 'a polyphony of battling and internally divided voices' as 'we would see them through each other's eyes' (Evans 2011:66). Broodthaers's reading of Mallarmé's text, in visual terms, as an image, exploits the artist's book as the most appropriate form in which to acknowledge the visual ${ }^{9}$ impact Mallarmé demanded of his text, as a 'divine and intricate organism required by literature' (Drucker 2007:36). Broodthaers succeeds in enunciating the conventions by which, through constant exposure, a book normally neutralises its identity (Drucker 2007:161).

A dialogical framework 'is itself not a systematic philosophy' and 'refuses to be systematic' (Holquist 2002:16) and, thus, constructs a space of polyvocality, and of simultaneity, within which artists' books may speak to one another and within which a productive theoretical position might be taken up. This simultaneity ('both' and 'and') (Holquist 2002:41) is a more useful position, and prevents reliance upon readings of categorisation such as similarity ('either' and 'or') in and between works which display purely formal, subject or broadly conceptual congruence or shared features. As Nelson Goodman (1972:437) has demonstrated, everything is similar to everything else in at least one respect, which leads to similarity being recognised as an 'insidious pretender' and 'an imposter'.

Dialogical simultaneity helps to find moments of intertextuality in which the artist self-consciously refers to the field of work they inhabit and the field refers back to the artist, which is what Bakhtin refers to as 'answerability'. An example of this is to recognise how the concepts, with which Broodthaers's Un coup de dés: Image grapple, might resonate with other artists who use Broodthaers's theoretical operation of enunciation as a starting point for their own work. This eliminates notions of formal or subject similarity in favour of a theoretically deeper analysis of intention and attention to the self-consciousness or reflexivity which provides artists' books with their peculiar and particular status. Clearly, Mallarmé's work is as reframed by Broodthaers's 'other' as Broodthaers's is by Mallarmé's.

\section{Buzz Spector}

If Broodthaers is acutely aware of the implications of cancellation and absence in his reference to Mallarmé, he would not be surprised to find examples of artists' books which pursue this trajectory and which may, themselves, include Broodthaers's work in their remit as a self-conscious act of dialogism. Renée and Judd Hubert (1999:87-89) read Buzz Spector's bookwork in just this way, accounting for his strategy of 'shortsheeting' existing texts. ${ }^{10}$ By carefully tearing down each page vertically, Spector removes most of the readable text and by progressively shifting the place of each tear, he increases the size of each successive partially surviving page. The result, when viewed either from the top

9.Arnar (2011:218-222) cites Mallarmé's use of visual and affective terms to describe the import he expected of his texts, which are active, performative, oceanlike, musical, thunder, ecstatic, glittering, sparking, electric and flickering.

10.Use of existing texts include The picture of Dorian Gray (1989) and Kafka (1988) and, less frequently, the use of a volume of blank pages in Silence (1991) and Malevich (1989). (see Hubert \& Hubert 1999:87-89). or the bottom, when closed, is a set of narrow, triangularly tapering books which only seem 'normal' when the spines are viewed on a bookshelf. In Marcel Broodthaers (1988), Spector uses the titular artist's exhibition catalogue as 'the sacrificial book' (Hubert \& Hubert 1999:88). The reconstructive and reductive elements of a catalogue are exploited by Spector's strategy, providing '... an additional means of deconstruction, for it dismantles fundamental aspects of the book for the sake of imposing an even more orderly design' (Hubert \& Hubert 1999:88). They continue by drawing attention to the manner in which the straight black lines of horizontal text, in the catalogue, give way to vertical opticality just as the many pages give way to a single sloping page made of pieces, where reading shifts to looking. Hubert and Hubert (1999:88-89) are aware of Spector's dialogical relationship with Broodthaers, the field of artists' books and a broader art and literary terrain they occupy when they state:

As Spector also produces texts, critical as well as meditative, we can classify him as a writer, in which capacity he deliberately makes himself vulnerable to his own artistic practice. (p. 89)

They continue:

The triumphant struggle with the word that Mallarmé had undertaken and that Broodthaers had visibly and editorially displaced, surfaces once again in the torn pages of the catalog. In a way, Spector has denied the word and image content of the catalog, and his negation may have produced an effect in keeping with that of the poem. (p. 89)

In dialogical terms, it becomes possible to pursue a theoretical reading of works which exploit the slippery terrain of image and text relationships, and appreciate them as part of an historically rich, polyvocal and simultaneous dialogue rather than in the more denuded terms of similarity in and of media, subject, style and craft practices. It is then possible to continue to find dialogues with artists' books which also reference or underscore alteration of existing texts, of which Tom Philips' A Humament (1966-1974) is perhaps the most well-known.

Hubert and Hubert (1999:71-95) explore particular artists' books as spaces of textual alteration, reassembly, juxtaposition, fragmentation, cancellation and mutilation, where each work is dialogically implicated with some extant, pre-exiting text. This is undertaken whilst forging links to other works which specifically impact upon existing texts, in order to construct a primarily visual or optical experience which replaces or obliterates the act of reading. This focus has the potential to refract all analogous works in both the history of art and literature to which it might respond or anticipate a response. ${ }^{11}$ Bakhtin's grappling with a neo-Kantian notion of 'things-in-themselves' also helps keep at bay the elevation of singular examples of artists' books for scrutiny, analysis and reification, forcing them to become answerable to the dialogical world of context, communication and community. In this way, dialogism opposes the dialectical 'either' and 'or' with 'both' and 'and' (Holquist 2002:41).

11.From here, the links and bridges are multiple: towards image and text discourses and semiotic analysis including the writings of W.J.T. Mitchell (1986) and Wendy Steiner (1982), or towards temporality in the artist's book. In these one might Steiner (1982), or towards temporality in the artist's book. In these one might
encounter the writings of book-arts theorist Anne Mœglin-Delcroix (1997) or even encounter the writings of book-arts theorist Anne Mœglin-
the recently resurrected ideas of Henri Bergson (1999). 

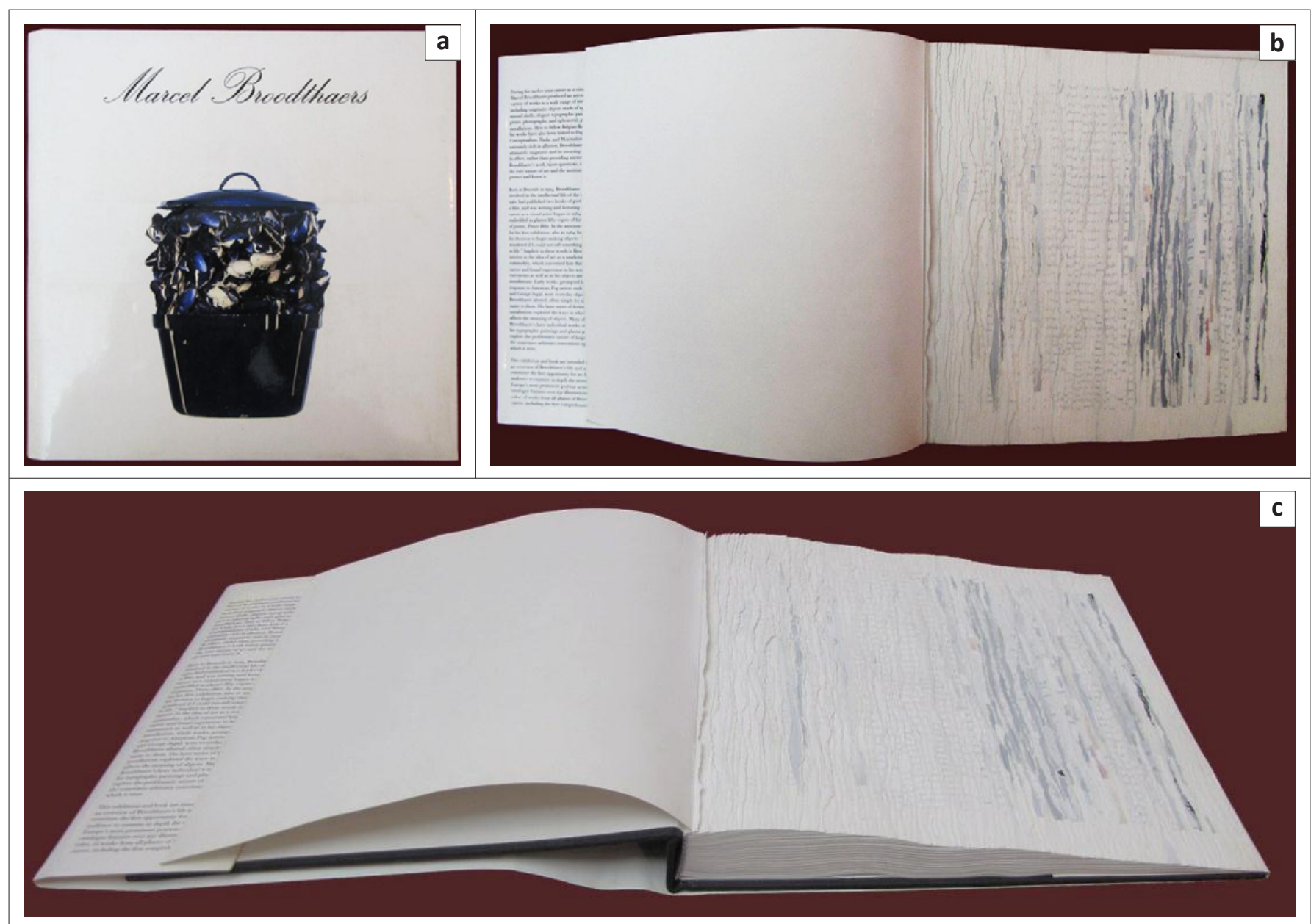

Source: Spector, B., 1988, 'Marcel Broodthaers. Alteration of Broodthaers' catalogue' (Artist's book)

Collection: Jack Ginsberg, Johannesburg

Photography: David Paton

Images reproduced courtesy of Buzz Spector, St. Louis, Missouri

Figure 2: (a) The cover of Spector's 1988 'Marcel Broodthaers exhibition catalogue' hides the interventions and alterations within; (b) The struggle with the word that Mallarmé had undertaken and that Broodthaers had displaced, surfaces in the torn pages of the catalogue. In this way, Spector denies the word and image content of the catalogue, producing an effect in keeping with Mallarmé's poem; (c) A view of Spector's strategy of shortsheeting in which the straight black lines of horizontal text give way to vertical opticality, where the many pages give way to a single sloping page and where reading shifts to looking.

If dialogism implies, also, an extra-literary language (Holquist 2002:107) which is non-systematic and liminal, bordering on multiple disciplines (Bakhtin cited in Holquist 2002:14) then I see it as an appropriate tool for the theoretical operation of enunciating artists' books in the world as well as in relation to each other. If the enunciation of artists' books can be considered, in Bakhtinian terms, as an 'utterance', then as Holquist (2002) states:

... texts, like other kinds of utterance, depend not only on the activity of the author, but also on the place they hold in the social and historical forces at work when the text is produced and when it was consumed. (pp. 60-61)

Of even greater importance to the manner in which action 'completes' the experience of the artist's book (and with particular relevance to Mallarmé) is Bakhtin's idea of the 'utterance as active and performed' (Holquist 2002:59). Dialogism, I argue, enunciates both the existence of the field of artists' books as well as its relationship with its own historiography, operating in temporal and spatial terms, between works separated in time.

\section{Heteroglossia and the artist's book}

Bakhtin's notion of heteroglossia, ${ }^{12}$ which operates underneath a broad dialogism, might help to operationalize the way in which artists' books enunciate themselves self-consciously and reflexively (Drucker 2007:161). This operation is important in demonstrating how artists' books call attention to themselves and de-neutralise their identities.

Sue Vice (1997:20) states that 'dialogism describes the way languages interact, while heteroglossia describes the languages themselves' whilst Holquist (2002:69) describes heteroglossia as governing the 'operation of meaning' in the kind of utterance we call texts, 'as it does in any utterance'.

This is derived from Julia Kristeva's (1980) spatial conception of language's poetic operation, which is the horizontal and the vertical status of the word.

12.In Bakhtinian terms, heteroglossia takes two general forms. Firstly, it takes the form of social languages within a single national language and, secondly, of different national languages within the same culture. Within the novel form, heteroglossia appears, firstly, as the dialogues of characters, secondly, as various forms of speech genre (language of a profession or class) and, thirdly, as a culture's various dialects and languages. Vice states that the manner in which these three interact in a text is dialogic. 


\section{Holquist (2002) continues:}

All utterances are heteroglot in that they are shaped by forces whose particularity and variety are practically beyond systematization. The idea of heteroglossia comes as close as possible to conceptualizing a locus where the great centripetal and centrifugal forces that shape discourse can meaningfully come together. (p. 70)

I have briefly and tentatively discussed centripetal and centrifugal heteroglosia before in relation to the imagistic texts of Jonathan Safran Foer and Willem Boshoff (Paton 2010:17-18), but here, there seems a need to forge a more coherent argument for the sake of a theoretical underpinning of the artist's book. Drucker's (2007:161) metacritical language of enunciation, in which the self-consciousness and self-reflexivity of the artists' books' are operationalised, seem heteroglossic in utterance. Thus, I must move cautiously here as a simple superimposition of Bakhtinian ideas onto a genre which was not part of his consciousness could be counterproductive. Bakhtin's focus on the novel, may help us isolate some critical operational elements of simultaneity with which to proceed. Firstly, Holquist (2002:72) states that 'Bakhtin is particularly drawn to the novel, the genre least secure (or most self-conscious) about its own status as a genre' (my italics). Secondly, he draws attention to '... the novel's peculiar ability to open a window in discourse from which the extraordinary variety of social languages can be perceived' (Holquist 2002:72). Thirdly, in relation to Bakhtin's two major protagonists and foci of study, Rabelais and Dostoevsky, Holquist (2002) states:

Rabelais and Dostoevsky are significant for Bakhtin not merely because they write novels, but because they advance the work of novelness, and it is novelness - not the novel, nor Rabelais, not even Dostoevsky - that is the name of his real hero. (pp. 72-73)

From this I can isolate three critical elements of Bakhtin's thought which might underpin the artist's book's theoretical act of enunciation: self-consciousness, discursive perceptivity and self-reflexivity (or bookness). Heteroglossia, I argue, activates these elements and governs the operation of meaning.

Bakhtin (cited in Vice 1997) tells us that heteroglossia is the following:

a double-voiced discourse, as it serves two speakers at the same time and expresses simultaneously two different intentions: the direct intention of the character who is speaking, and the refracted intention of the author. (p. 19)

Heteroglot differences can produce a variety of effects related to time (past and present), space (geography, nationality) and class, amongst other differences (Vice 1997:21). As Bakhtin (1975) in Discourse in the novel $(D N)^{13}$ points out, heteroglossia:

represents the co-existence of socio-ideological contradictions between the present and the past, between differing epochs of the past, between different socio-ideological groups in the present, between tendencies, schools, circles, and so forth, all given a bodily form. (p. 291)

13.This work was first written between 1934 and 1938, published in Russian in 1975 and translated and published in English in 1981

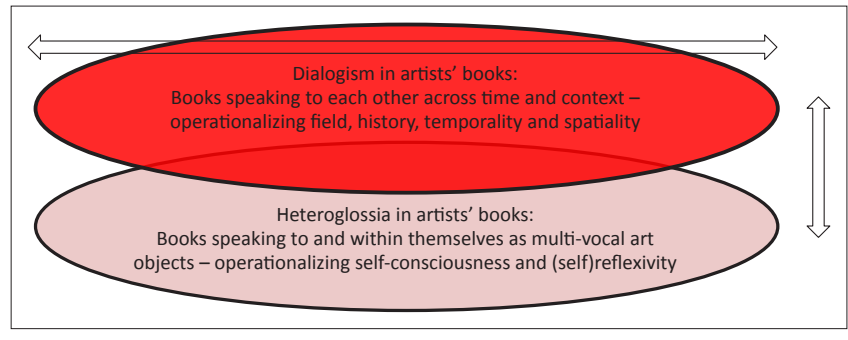

Source: Adapted from Kristeva, J., 1980, Desire in language: A semiotic approach to literature and art, Columbia University Press, New York.

FIGURE 3: A conceptual map of artists' books' broad dialogism which operates across time and context and under which, heteroglossia is able to operationalise the genre's self-conscious and reflexive qualities.

Bakhtin (1975:292) continues by suggesting that such difference represents 'specific points of view on the world' which will 'mutually supplement one another, contradict one another and be interrelated dialogically'. Bakhtin's positioning of heteroglossia, as multiple languages and 'registers' or 'sociolect' voices (Vice 1997:18), suggests not only the novel's double-voiced construction of characters and narrators but also the self-conscious awareness of the construction of a work's content, shot-through with heteroglot utterances of different kinds, which are:

- stylisation

- comic, ironic or parodic discourse

- the refracting discourses of the narrator and the languages of a character, author and whole 'incorporated genres' (1975:324).

More importantly to my argument, Bakhtin (1975:321) asserts that these incorporated genres include 'non-literary forms (menus, advertisements)', and it is here where his heteroglossic discursive perceptivity opens itself to the possibility of imagistic and other forms of scripto-visual text for inclusion and analysis.

The socio-political context in which Bakhtin theorised the novel's importance supports his argument that, once it enters a text, heteroglossia is automatically 'consciously opposed' to 'the linguistic centre of the verbal-ideological life of the nation and the epoch' (1975:273). This positioning of texts, as implicated in the political life of societies, can help to contextualise how, when and why the artist's book rose to prominence in the 1960s, signalling a form which consciously attempted to disrupt, de-centre and oppose the authority of the livre d'artiste, the fine-press book, the illustrated works of literature and, in fact, any authoritative monoglossic tome including, in some instances, the artist's catalogue. The artist's book even exploits the seemingly private text, some of which Bakhtin (1975:321) identifies as 'the confessional, the diary, travel notes, biography, [and] the personal letter', any of which have found themselves meaningful subjects of artists' books. In heteroglossic terms, the author, the narrator, (other) characters and the reader, become the artist, subjects, characters, characterisations and the viewer, each aware of the positions and roles the others take up and play. Any textual or scripto-visual utterance in the artist's book, then, is dialogilised heteroglossia. 
It is clear how Broodthaers's Un coup de dés: Image enters into a self-conscious and reflexive dialogue with Mallarmé's original by opening a discursive window on a particular variety of social, formal or artistic utterance. Broodthaers's cancellation of Mallarmé's poem reveals a dialogue on multiple levels. These are:

- the relation and refraction of author to, or by, author

- the 'authoritative act' which refers the reader or viewer back to the original and, thus, makes the original stronger by means of this reference-in-cancellation

- the meta-language of an image (black lines of various widths, heights and densities) as a text of cancellation

- the manner in which an image of the textual layout and spacing of the double page-openings is a referent to the subversion of literary and visual conventions of the page (Drucker 2007:163, 168).

This heteroglossia of authorial voice (or its absence), image as text, text as referent and reflexive self-consciousness of the form, seems a powerful reminder that just as novelness is the 'real hero' to Bakhtin's writer, so interrogating bookness is to the artist. Anything less, Wayne Booth (1982) describes (in Morson 1986), is to deny Bakhtin's:

insistence on the supreme value, in art as in life, of resisting monologue ... whatever counters the temptation to treat human beings as 'objects'. ... People are essentially, irreducibly 'subjects', voices rich beyond anyone's uses ... (p. 152)

\section{Ulises Carrión}

I now cojoin two selected examples of artists' books with heteroglossia as a frame for explaining how selfconsciousness and self-reflexivity operate. For the purposes of forging a heteroglossic reading in my selected examples,
I have chosen works which utilise or exploit scripto-visual texts, specifically from outside a myriad of possible examples from Duchamp to Fluxus and concrete poetry which, it may be argued, utilise book forms outside the concerns of the artist's book. It is for this reason that I look, firstly, at Ulises Carrión's For fans and scholars alike (1987), which distinguishes itself from the work of concrete poets that:

are only sometimes book works, far more frequently, single poems produced over a few pages or as a single sheet (Drucker 2007:195n1) and in which he attends to the book as a whole. (p. 164)

The layout of each page is composed in the visual language of the magazine or book divided into column blocks, which frame spaces for illustrations and create space for headings. The page is an image of literary conventions in which the gutter, marginalia, indices, running heads and footers 'are so codified that they can be quoted without any verbal content, as shapes and forms on the page and function as a selfconscious investigation' (Drucker 2007:163). This codified language, however, is double-voiced: Carrión composes his text blocks entirely of the letter ' $i$ ' with 'headlines' made up of bracket-like shapes and with the 'illustrations' containing graphic marks 'taking up space as if they comprised a readable image' (Drucker 2007:164). The grey cover boards contain the same ' $i$ ' imagery; an undifferentiated space whether external or internal and in which the voice of the book's narrative is the same as the one which announces the book on the cover. The title, too, points us towards the double-voicedness of Carrión's project. Drucker (2007) states:

The book displays a self-conscious level of organization as a structural feature of the work. ... But the book is neither nonsense (silly gibberish) nor without sense (meaningless) instead it represents structure as meaning. (p. 164)

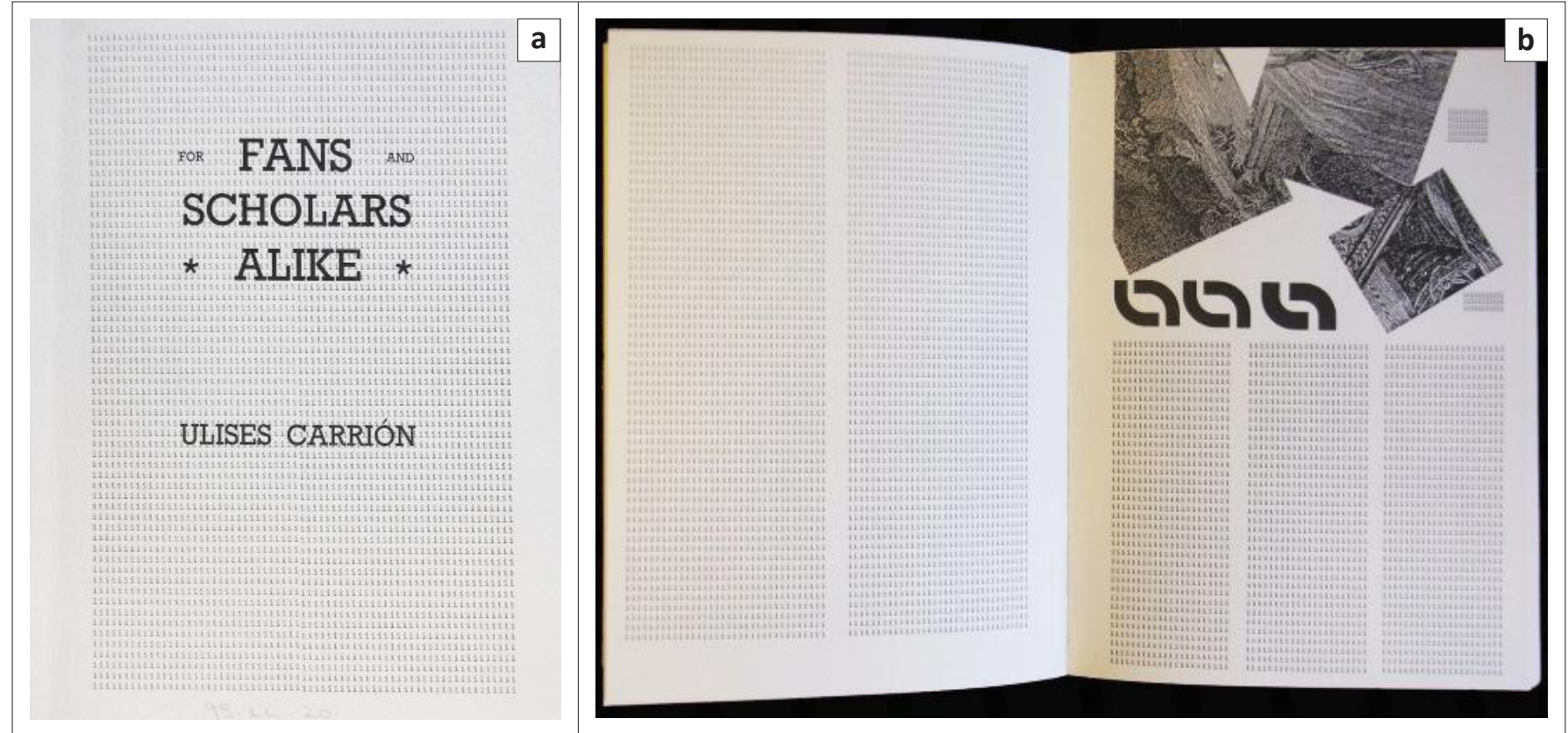

Source: Carrión, U., 1987, For fans and scholars alike, Visual Studies Workshop Press, Rochester. (Artist's book)

Collection: National Art Library, V \& A Museum, London

Photography: David Paton

Images reproduced courtesy of Martha Hellion, Mexico

FIGURE 4: (a) The cover of Ulises Carrión's 1987 For fans and scholars alike; (b) An interior spread in which a self-conscious level of organisation represents structure as meaning. 
Carrión's character, ' $i$ ', serves to represent the physical space which it self-consciously occupies whilst, at the same time, the conventions of the occupied space articulate the space as the ' $i$ ' of the narrative. For Carrión, as author, however, this double-voiced self-consciousness is predicated upon a reflexive, small ' $i$ '. Holquist (2002) referencing Jacobson suggests the following, that:

' $\mathrm{I}$ ' is a 'shifter' because it moves the center of discourse from one speaking subject to another: its emptiness is the no man's land in which subjects can exchange the lease they hold on all of language by virtue of saying 'I.' ... 'I' is the invisible ground of all other indices in language, the benchmark to which all its spatial operations are referred, and the Greenwich mean by which all its time distinctions are calibrated. ' $\mathrm{I}$ ' marks the point between 'now' and 'then,' as well as between 'here' and 'there'. (p. 23)

Carrión's small ' $i$ ' is a self-consciously articulated, depersonalised, heteroglossic voice and, as such, an example of Jacobson's referential shifter in which the 'now' and 'here' of the space of the page as well as the reiterated and reinforced visual analogue (Drucker 2007:164) of the book's whole are articulated. Carrión (1980:25) states: 'Bookworks are books that are conceived as an expressive unity, that is to say, where the meaning is the sum of all the material and formal elements'. Hubert and Hubert (1999:7), in reference to the notorious absence of definitiveness in the field of artists' books, seem to suggest that the heteroglossia, evident in Carrión's For fans and scholars alike, acts as a unifying utterance on what constitutes meaningfulness in an utterly open-ended field.

\section{Helen Douglas and Telfer Stokes}

The second example of heteroglossia in an artist's book is provided by Helen Douglas' and Telfer Stokes' Real fiction: An enquiry into the bookeresque (1987). Again, the title signals something of potential significance for my concerns. Hubert and Hubert (1999) state:

The authors/artists have contrived a book abounding in thresholds and antithesis. This begins immediately with the oxymoronic title, where the word 'real,' functioning as an

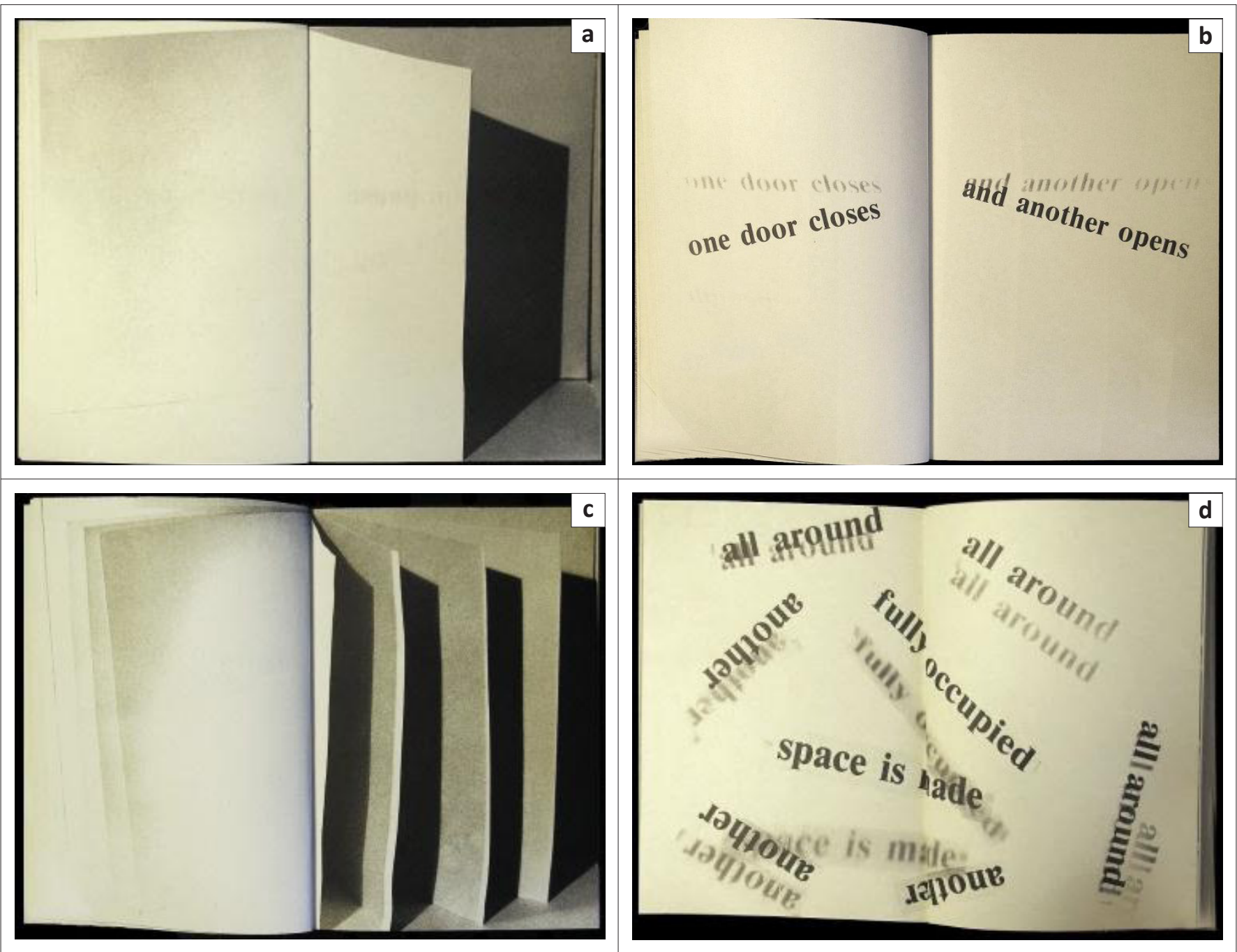

Source: Douglas, H. \& Stokes, T. 1987, Real fiction: An enquiry into the bookeresque, Visual Studies Workshop Press, Rochester Collection: National Art Library, V \& A Museum, London

Photography: David Paton

Images reproduced courtesy of Helen Douglas, Deuchar Mill, Yarrow

FIGURE 5: (a) An interior spread in which the illusory shadow of an illusory page is 'cast' on the actual page; (b) An interior spread in which the illusory shadow of an illusory floating text is 'cast' on the actual page; (c) An interior spread in which the illusory shadows of illusory pages are 'cast' on the actual page evoking an architectural structure; (d) An interior spread in which illusory shadows of illusory scattered texts are 'cast' on the actual page. 
adjective, makes the fictive element even more fictional. The term 'fiction' etymologically derives from 'fingere,' the action of fashioning an object and implies creativity, in this instance the architectural. Photographs show us buildings and rooms at various stages of completion and demolition. Taken selfreferentially, the title may designate the making of the book: real fashioning as opposed to figments of the imagination. (p. 37)

Douglas and Stokes' notion of 'the bookeresque' invites further comparison with the theoretically loaded concept of bookness and, like Carrión, exploits and undermines conventional scripto-visual placements as well as the literal flatness associated with the printed page. Stokes (cited in Hubert \& Hubert 1999:33) defines a word and image relationship as 'antagonistic sympathy ... whereby the verbal and the visual exchange some of their characteristics'. In this example Jacobson's referential shifter marks multiple points between 'here' and 'there' as well as between 'now' and 'then'. But in this instance, the shifter is no longer ' $\mathrm{I}$ ' but the works titular paradox and its implication for the complex interplay between texts as images and of images as texts of interior versus exterior force. Verbal rivalry characterises the text, with spatial rivalry dominating the imagery. 'More perhaps than in any other artist's book,' state Hubert and Hubert (1999), concerning the magnet metaphor that reminds us of Mallarme's textual-poetic desire:

raw material, either visual or textual, does everything in its power to participate in the fabrication of a book, as though a magnet had drawn everything unto itself. (pp. 39)

Drucker (2007) describes the heteroglossic terms of the work's texts of representation as:

The 'real' is both the literal reality of the book and the reality external to the book which can only be represented as a fiction (incomplete, contrived, un-'true' because it is a representation 'real' because it is an actual book). (p. 192-193)

Multiple voices, often in the contrived guises of 'something else' abound in the book, which Drucker (2007) describes as follows:

In the first opening, the shadow of a page on the left hints at the shadow of a structure on the right which quotes the book form as an element of architectural space. The opening reads as book, page, wall, room. The next opening reads 'there are two sides to every opening' and the type appears to float above the page casting its shadow as if on a page curled downward far more radically than the page on which the words are printed. Thus in two openings we have already encountered several levels of reference to the book as a space of representation and illusion, of appearances and realities, literal surfaces and their imitation as delusions. (p. 193)

Visual elements of opening pages and doors (both of which require opening), walls and bricks rub shoulders with photographs of these elements, and are the most representational and believable visual elements of the fiction. But even they become merely material through cutting, cropping, folding and other forms of physical manipulation. Devices of framing and of being framed, speaking and being echoed, represent the manner in which a book comes to 'contain' the things that it does (Drucker 2007:195) and whereby self-referentiality and reflexivity are uttered in a polyglot, double-voiced and dialogic manner. And in this way, Drucker (2007):

the meaning of the book as a boundary, a point of delimitation and demarcation on the one hand, and the meaning of the book as a space, infinitely imaginable and expandable on the other hand, are explored as two aspects of the paradoxical nature of the book [of its very bookness and of its extreme self-consciousness.] (p. 195)

Exactly who and indeed where are the authors' voices in this 'builder's rubble' of self-referentiality and reflexivity? Hubert and Hubert (1999:33) describe the book as having generated itself. It seems as if the book shakes off its relationship with its author's voice, and articulates a voice of its own. The black letters, after all, cast their own shadows as if they are concrete things, perhaps more concrete than the raw 'building materials' which function to fabricate the book. And if not concrete, then to echo as if calling across the temporal-spatiality of the book, which is what Kristeva (1980) terms a Bakhtinian intertextuality and Bakhtin (cited in Pechey 1989:41) terms translinguistics, which is the notion of a boundary transgressed. If heteroglossia is differentiated speech, then Real fiction speaks with the parodic and ironic tongues to which Bakhtin (1975:324) might have referred as, 'another's speech in another's language'. It remains, for another time, however, to see how the artist's book might embody Bakhtin's idea of the carnivalesque.

\section{Conclusion}

In this article I have attempted to respond to a perceived gap in the theoretical underpinning of the artist's book. I have shown that, despite a number of research projects and conferences in which a desire for theory has been articulated, Johanna Drucker's call for more critical work to be undertaken continues to require much effort. My response draws together specific examples of artists' books: Marcel Broodthaers's Un coup de dés: Image, which responds to Stéphane Mallarmé's original work, Buzz Spector's Marcel Broodthaers, Ulises Carrión's For fans and scholars alike and Helen Douglas' and Telfer Stokes' Real fiction, and exposes these works to the critical and framing lenses of Bakhtin's writings on dialogism and heteroglossia. I do this in order to shed light on how artists' books enunciate themselves as particularly selfconscious and self-reflexive objects which open up a space of discursive perceptivity. I will, thus, conclude tentatively that Bakhtin's notions of dialogism and heteroglossia do provide a theoretical foundation for the artist's book as a dynamic visual language, which is relational and engaged in a process of endless redescriptions of the world.

\section{Acknowledgements Competing interests}

The author declares that he has no financial or personal relationships which may have inappropriately influenced him in writing this article. 


\section{References}

Arnar, A.S., 2011, The book as instrument, Stéphane Mallarmé. The artist's book, and the transformation of print culture, The University of Chicago Press, Chicago.

Bakhtin, M., 1975, 'Discourse in the novel', in M. Holquist (ed.), 1981, transl. by C. Emerson \& M. Holquist, The dialogic imagination: Four essays by M. M. Bakhtin. University of Texas Press, Austin.

Bergson, H., 1999, Duration and simultaneity, transl. R. Durie (ed.), Clinamen Press, Manchester.

Besley, T. \& Peters, M., 2011, 'Intercultural understanding, ethnocentrism and western forms of dialogue', Analysis and Metaphysics 10, 81-100.

Bhabha, H.K., 1994, The location of culture, Routledge, London.

Bodman, S. \& Sowden, T., 2010, A manifesto for the book, Impact Press, Bristol.

Booth, W.C., 1982, 'Freedom of interpretation: Bakhtin and the challenge of feminist criticism', in G.S. Morson (ed.), 1986, Bakhtin. Essays and dialogues on his work, pp. 145-176, The University of Chicago Press, Chicago.

Broodthaers, M., 1969, 'Un coup de dés jamais n'abolira le hasard: Image', Galerie Wide White Space and Köln: Galerie Michael Werner, Antwerp. (Artist's book).

Carrión, U., 1980, Second thoughts, Void Distributors, Amsterdam.

Carrión, U., 1987, For fans and scholars alike, Visual Studies Workshop Press, Rochester (Artist's book).

Dietrich, K., 2011, Intersections, boundaries and passages: Transgressing the codex Sunprint Press, Stellenbosch.

Douglas, H. \& Stokes, T., 1987, Real fiction: An enquiry into the bookeresque, Visual Studies Workshop Press, Rochester.

Drucker, J., 2005, 'Critical issues / exemplary works', The Bonefolder 1(2), 3-15.

Drucker, J., 2007, The century of artists' books, Granary Books, New York.

Evans, F., 2011, The multivoiced body. Society and communication in the age of diversity, Columbia University Press, New York.

Goodman, N., 1972, Problems and projects, Bobbs-Merrill, Indianapolis.

Higgins, D., 1985, 'A Preface', in J. Lyons (ed.), Artists' books: A critical anthology and sourcebook, pp. 11-12, Visual Studies Workshop Press, Rochester.
Holquist, M., 2002, Dialogism. Bakhtin and his world, Routledge, London.

Holquist, M. (ed.), 1981, The dialogic imagination: Four essays by M.M. Bakhtin transl. C. Emerson \& M. Holquist, University of Texas Press, Austin.

Hubert, R.R. \& Hubert, J.D., 1999, The cutting edge of reading: Artists' books, Granary Books, New York.

Kristeva, J., 1980, Desire in language: A semiotic approach to literature and art, Columbia University Press, New York.

Long, E., 2007, 'Conference overview', Journal of Artists' Books 22, 4-6.

Mallarmé, S., [1914] 2003, Un coup de dés jamais n'abolira le hazard, Gallimard, L'imprimerie Floch, Paris/Mayenne.

Mitchell, W.J.T., 1986, Iconology: Image, text, ideology, University of Chicago Press, Chicago.

Mœglin-Delcroix, A., 1997, Esthétique du livre d'artiste 1960-1980, Jean-Miche Place/Bibliothèque Nationale de France, Paris.

Paton, D., 2010, 'The book arts as a community of practice: Some thoughts on the research project $A$ manifesto for the book, what will be the canon for the artist's book in the 21st century?' in L. Farber (ed.), On making: integrating approaches to practice-led research in art and design, pp. 209-221, VIAD, University of Johannesburg, Johannesburg.

Pechey, G., 1989, 'On the borders of Bakhtin: dialogisation, Decolonialisation', in K. Hirschop \& D. Shepherd (eds.), Bakhtin and cultural theory, Manchester University Press, Manchester

Pelzer, B., 1987, 'Recourse to the letter', transl. R. Miller, October 42, 157-181.

Philips, T., 1966-1974, A humament. Artist's book: Alteration of Mallock. W.H., 1892 A human document.

Spector, B., 1988, 'Marcel Broodthaers. Alteration of Broodthaers' catalogue'. (Artist's book).

Steiner, W., 1982, The colors of rhetoric: Problems in the relations between modern literature and painting, University of Chicago Press, Chicago.

Turner, V., 1967, The forest of symbols: Aspects of Ndembu ritual, Cornell University Press, Ithaca, New York.

Vice, S., 1997, Introducing Bakhtin, Manchester University Press, Manchester. 